\title{
Title:
}

\section{Brunneroma: an infrequent duodenal neoplasm}

\section{Authors:}

Pablo Olcina Domínguez, Luis Estela Villa, Arancha Villadóniga Sánchez, Rocío Avellana Moreno, Sergio Gil Rojas, Jesús García-Cano Lizcano

DOI: $10.17235 /$ reed.2021.8349/2021

Link: PubMed (Epub ahead of print)

Please cite this article as:

Olcina Domínguez Pablo, Estela Villa Luis, Villadóniga Sánchez Arancha, Avellana Moreno Rocío, Gil Rojas Sergio, García-Cano Lizcano Jesús. Brunneroma: an infrequent duodenal neoplasm. Rev Esp Enferm Dig 2021. doi: 10.17235/reed.2021.8349/2021.

This is a PDF file of an unedited manuscript that has been accepted for publication. As a service to our customers we are providing this early version of the manuscript. The manuscript will undergo copyediting, typesetting, and review of the resulting proof before it is published in its final form. Please note that during the production process errors may be discovered which could affect the content, and all legal disclaimers that apply to the journal pertain. 


\section{Brunneroma: an infrequent duodenal neoplasm}

Pablo Olcina Domínguez (1). Luis Estela Villa (2). Arancha Villadóniga Sánchez (2). Rocío Avellana Moreno (3). Sergio Gil Rojas (1). Jesús García-Cano Lizcano (1).

1. Servicio de Aparato Digestivo. Hospital Virgen de la Luz. Cuenca. Spain.

2. Servicio de Cirugía General y Aparato Digestivo. Hospital Virgen de la Luz. Cuenca. Spain.

3. Servicio de Cirugía General. Hospital Clínico San Carlos. Madrid. Spain.

Pablo Olcina Domínguez

E-mail: olcinapod@gmail.com

Servicio de Aparato Digestivo. Hospital Virgen de la Luz. Cuenca. España.

Dear Editor,

An 83-year-old male presented at our institution's emergency department with long lasting epigastric discomfort, weight loss and diarrhea. Physical exam and basic laboratory tests showed no remarkable findings. Upper endoscopy revealed in the anterior wall of the duodenal bulb a sessile lesion (Paris 0-Ila) with smooth surface, slightly ulcerated at its top (figure $1 \mathrm{~A}$ ). Biopsies demonstrated a protein background and intestinal epithelium without dysplasia. Endoscopic ultrasound found a hypoechogenic oval lesion with a heterogenic content and cystic areas, dependent on the submucosal layer without infiltration signs (figure 1B). A CT scan showed an $18 \mathrm{~mm}$ duodenal lesion without infiltration, suggestive of gastrointestinal stromal tumor (figure 1C). Somatostatin-receptor scintigraphy was normal although an increased in serum cromogranine was found. After discussion in the oncologic committee at our institution, a laparoscopic resection was planned. Surgical full-thickness resection of the posterior wall of the duodenal bulb and primary closure was performed (figure 
1D). The postoperative period was uneventful and a histologic diagnosis of Brunneroma was made. The patient remains asymptomatic 6 months after surgery. Brunneroma or Brunner gland's adenoma is an uncommon type of gastrointestinal tumor (1)

Brunner glands are located in the duodenal bulb deep mucosa, and secrete bicarbonate and mucus to neutralize acid secretion from the stomach. A Brunneroma, is a benign neoplasm, a hamartoma of Brunner glands which can also contain adipose tissue, smooth muscle and lymphoid cells (2). This lesion is usually benign, notwithstanding that a $0,3 \%$ malignant transformation has been reported (3). They are mostly asymptomatic although in some cases hemorrhage, obstruction or compression due to lesion growth can be seen (4). After the initial finding in upper endoscopy, endoscopic ultrasound is the most useful method to rule out deep invasion $(1,5)$. Treatment is based on polypectomy, endoscopic mucosal resection or surgical laparoscopic resection (3).

\section{REFERENCES:}

1. Guo $T$, Tan $Y$, Liu D, A rare mass in the duodenum bulb: Brunner's glands cystadenoma. Rev Esp Enferm Dig 2018, 110(3);199-200

2. Kim K., Jang S. J., Song H. J., et al. Clinicopathologic characteristics and mucin expression in Brunner's gland proliferating lesions. Digestive Diseases and Sciences. 2013;58(1):194-201. doi: 10.1007/s10620-012-2320-3.

3. Zhu M, Li H, Wu Y, et al. Brunner's Gland Hamartoma of the Duodenum: $A$ Literature Review. Adv Ther. 2021;38(6):2779-2794. doi:10.1007/s12325-021-01750-6

4. Bayan $\mathrm{K}$, Tüzün $\mathrm{Y}$, Yilmaz $\mathrm{S}$, et al. Pyloric giant Brunner's gland hamartoma as a cause of both duodenojejunal intussusception and obscure gastrointestinal bleeding. Turk J Gastroenterol. 2009;20(1):52-56.

5. Lee KJ, Park B, Kim HM. Endoscopic Ultrasonography Findings for Brunner's Gland Hamartoma in the Duodenum [published online ahead of print, $2021 \mathrm{Apr}$ 28]. Clin Endosc. 2021 

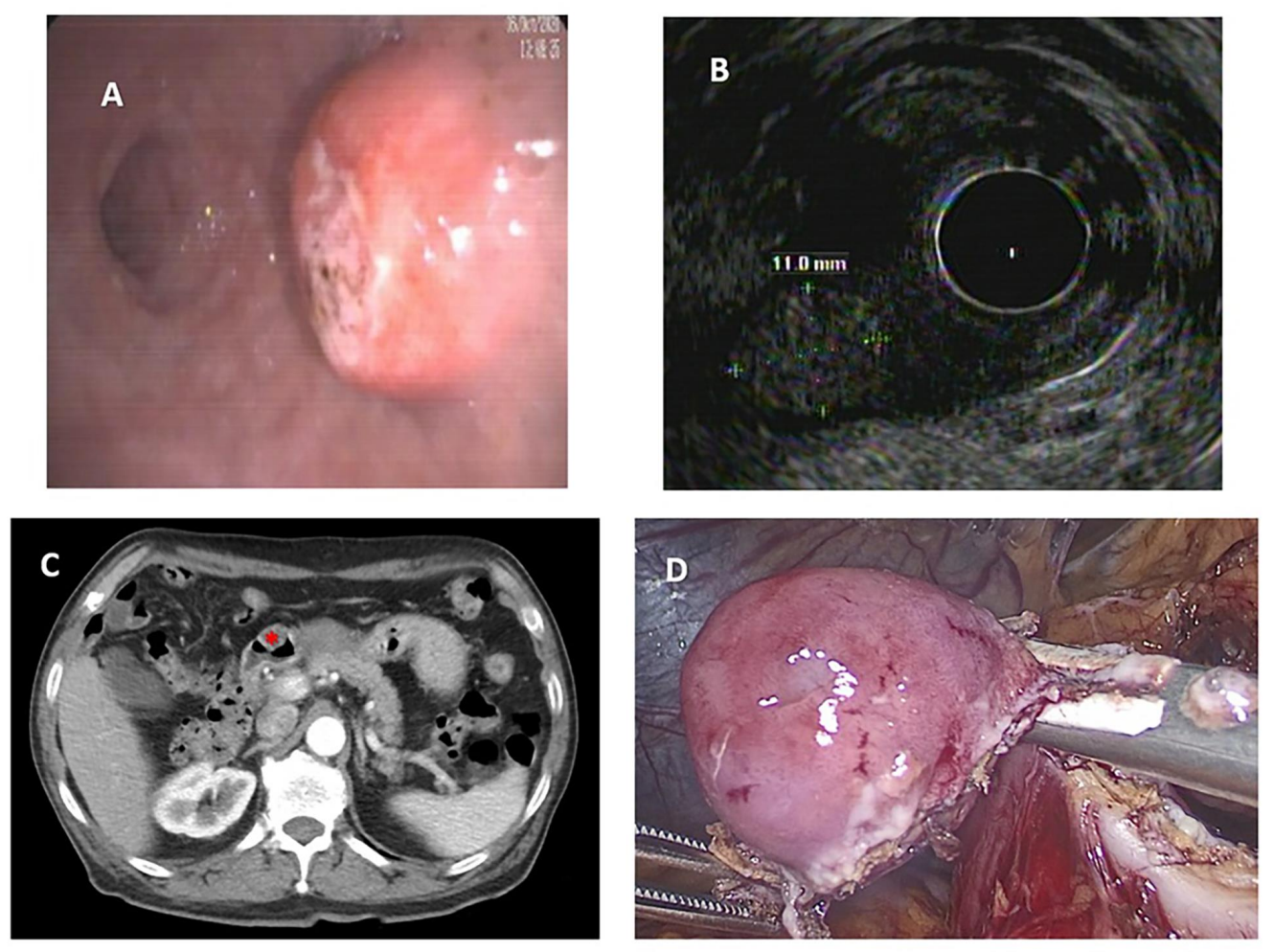

Fig1. A. Endoscopic vew of duodenal bulb lesion. B. Endoscopic ultrasound image of the lesion C. CT scan $\left({ }^{*}\right)$ D: Laparoscopic resection of the lesion 